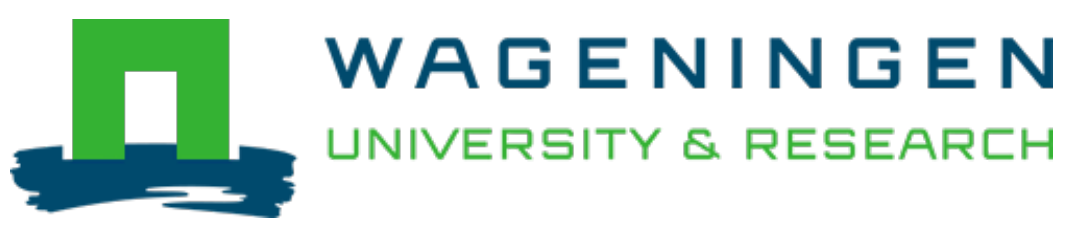

\author{
Sex differentiation in seasonal distribution of the starry smooth-hound Mustelus \\ asterias \\ Journal of Fish Biology \\ Brevé, Niels W.P.; Winter, Hendrik V.; Wijmans, Paul A.D.M.; Greenway, Eleanor S.I.; Nagelkerke, Leopold \\ A.J. \\ https://doi.org/10.1111/jfb.14548
}

This article is made publicly available in the institutional repository of Wageningen University and Research, under the terms of article $25 \mathrm{fa}$ of the Dutch Copyright Act, also known as the Amendment Taverne. This has been done with explicit consent by the author.

Article 25 fa states that the author of a short scientific work funded either wholly or partially by Dutch public funds is entitled to make that work publicly available for no consideration following a reasonable period of time after the work was first published, provided that clear reference is made to the source of the first publication of the work.

This publication is distributed under The Association of Universities in the Netherlands (VSNU) 'Article $25 \mathrm{fa}$ implementation' project. In this project research outputs of researchers employed by Dutch Universities that comply with the legal requirements of Article $25 \mathrm{fa}$ of the Dutch Copyright Act are distributed online and free of cost or other barriers in institutional repositories. Research outputs are distributed six months after their first online publication in the original published version and with proper attribution to the source of the original publication.

You are permitted to download and use the publication for personal purposes. All rights remain with the author(s) and / or copyright owner(s) of this work. Any use of the publication or parts of it other than authorised under article $25 \mathrm{fa}$ of the Dutch Copyright act is prohibited. Wageningen University \& Research and the author(s) of this publication shall not be held responsible or liable for any damages resulting from your (re)use of this publication.

For questions regarding the public availability of this article please contact openscience.library@,wur.nl 


\title{
Sex differentiation in seasonal distribution of the starry smooth-hound Mustelus asterias
}

\author{
Niels W. P. Brevé ${ }^{1}$ (c) | Hendrik V. Winter ${ }^{2}$ ( ) | Paul A. D. M. Wijmans ${ }^{1}$ | \\ Eleanor S. I. Greenway ${ }^{3}$ ๑) | Leopold A. J. Nagelkerke ${ }^{4}$ (i)
}

\author{
${ }^{1}$ Sportvisserij Nederland, Bilthoven, \\ The Netherlands \\ ${ }^{2}$ Wageningen Marine Research, IJmuiden, \\ The Netherlands \\ ${ }^{3}$ The University of Groningen, Groningen, \\ The Netherlands \\ ${ }^{4}$ Wageningen University \& Research, \\ Aquaculture and Fisheries group, Wageningen, \\ The Netherlands \\ Correspondence \\ Niels W. P. Brevé, Sportvisserij Nederland, \\ Leijenseweg 115, 3721 BC Bilthoven, \\ The Netherlands. \\ Email: breve@sportvisserijnederland.nl
}

\begin{abstract}
This mark-recapture study of starry smooth-hound Mustelus asterias tagged during the summer months near the Dutch coast demonstrates a large-scale spatial sex differentiation in their circannual migration patterns and small-scale spatial sex differentiation during summer. Overwintering occurs in the North Sea, English Channel and Bay of Biscay, with significantly more males in the Northern North Sea and more females in the Bay of Biscay. During summer, sheltered sea arms off the Dutch coast were almost exclusively used by adult females. In subsequent summers post-release, both sexes were mostly confined to the Southern North Sea, suggesting philopatry.

\section{KEYWORDS}

elasmobranchs, Greater North Sea, mark-recapture programme, seasonal migration, sharks
\end{abstract}

Elasmobranch species play important roles in marine food webs, but are also especially vulnerable to human intervention, such as fisheries, because of their K-selected life history strategies, characterized by late attainment of sexual maturity, low fecundity and slow growth (Musick et al., 2000; Myers et al., 2007; Stevens et al., 2000). However, effective management aimed at sustainable exploitation and conservation of these species is often not in place or hampered by a lack of relevant biological knowledge (Farrell et al., 2010a; Dulvy et al., 2014). The starry smooth-hound Mustelus asterias Cloquet 1819 is one such species, although its reproductive biology and life history has recently been described in some detail (Farrell et al., 2010a,b, 2014; McCully Phillips and Ellis, 2015), its movement ecology, which is relevant for effective management, is still poorly understood. M. asterias is a medium-sized (up to $140 \mathrm{~cm}$ total length, $L_{T}$ ) demersal, viviparous shark (Compagno, 1984), which is widespread in the Mediterranean and the north-east Atlantic where the species populates waters of the continental shelf in ICES Subareas 4, 6-8 (Burt et al., 2013; ICES, 2019).

* Funding Information

This study was supported by the World Wide Fund for Nature (WWF), The Dutch Shark Society and The Royal Dutch Angling Association (Sportvisserij Nederland) as part of the project "Sharks and rays back to the North Sea!"
M. asterias expresses larger length at $50 \%$ maturity in the Irish and Celtic Seas (78 and $87 \mathrm{~cm}$ for males and females, respectively; Farrell et al., 2010a) than in the Greater North Sea (70.4 and $81.9 \mathrm{~cm}$; McCully Phillips and Ellis, 2015). The latter values were used in the present study, as specimens were captured and tagged in this area. Parturition occurred in February in the western English Channel and during June to July in the eastern English Channel and Southern North Sea. This could be an indication of protracted spawning, asynchronous parturition of the stock (McCully Phillips and Ellis, 2015), or the presence of different stocks (Brevé et al., 2016). However, in the absence of more detailed studies, the Working Group on Elasmobranch Fishes (WGEF) considers there to be a single biological stock unit (ICES, 2019).

At present, there is no species or stock-specific management for M. asterias, even though there has been an unregulated rapid rise in bycatches (Silva and Ellis, 2019) and a population collapse of closely related Mustelus species in the Mediterranean (Colloca et al., 2017, 2020). As a result, in 2015 the status of M. asterias was upgraded from "Least Concern" to "Near Threatened" (Nieto et al., 2015). This justifies the prioritization of studies on behaviour, habitat use and movement patterns (Williamson et al., 2019). Brevé et al. (2016), using a mark-recapture programme, showed indications of seasonal migration 

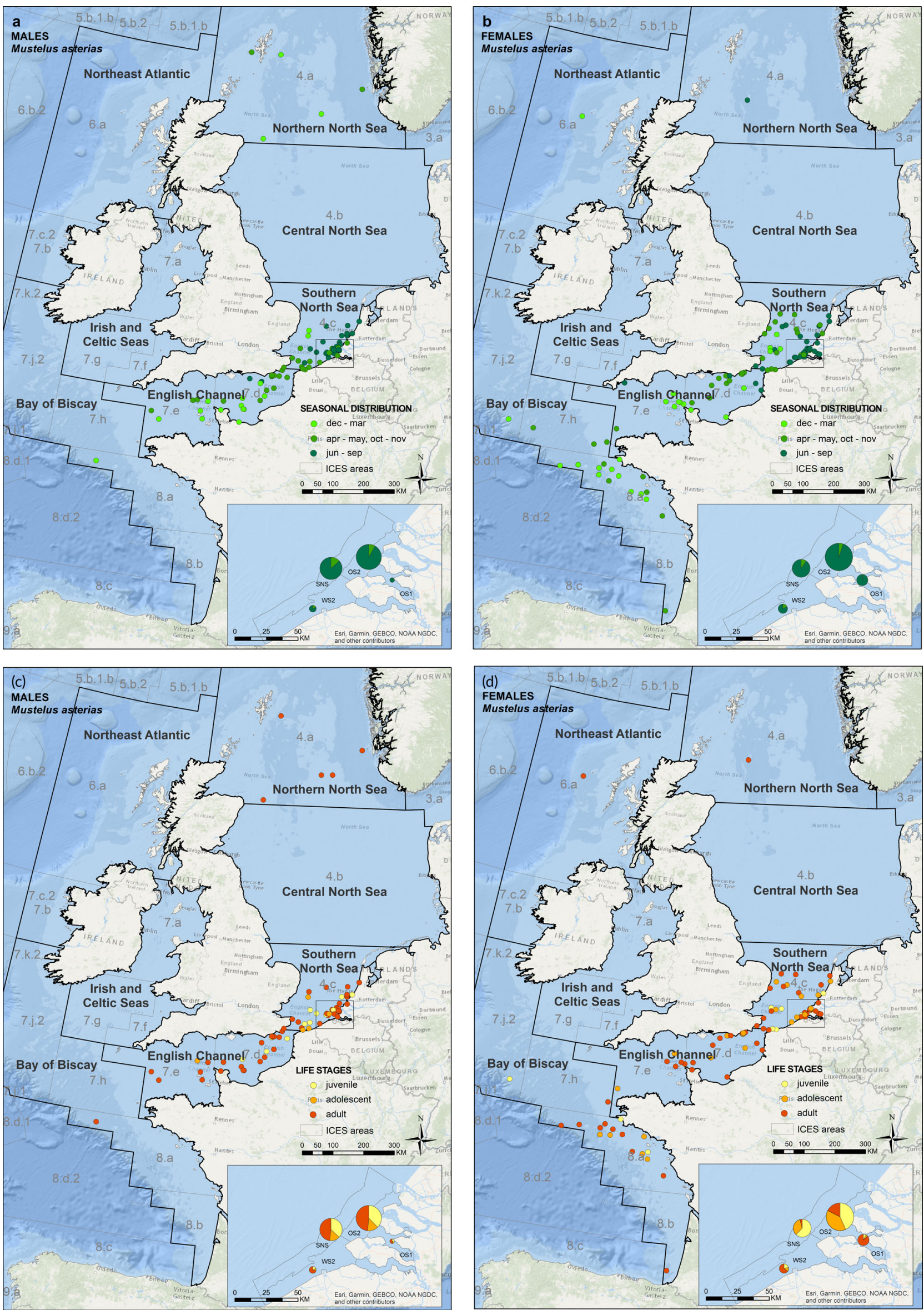

FIGURE 1 Legend on next page. 
patterns of M. asterias and of nonmixing between M. asterias from the North Sea and Celtic Sea during summer. The present study is based on a continuation of the mark-recapture programme for four more years and aimed to further determine seasonal distributions of M. asterias to support sustainable and meaningful management of the species.

Between June 2011 and August 2019, a total of 4495 individuals of $M$. asterias were captured during a long-term angler-led tagging programme. Of these, in total 3699 individuals (> $40 \mathrm{~cm} L_{T}$ ) were IDtagged with plastic rototags attached to the base of the first dorsal fin, as described in Brevé et al. (2016). Sharks were caught by a group of licensed taggers that included 28 recreational anglers and one electric pulse trawler. Fishing occurred in ICES area 4.c., that is, in the river Scheldt outer estuary (Westerschelde) and the adjacent sea arm in the Netherlands (Oosterschelde). During the whole study period $99.9 \%$ of all M. asterias individuals were caught between May and October, even though fishing continued throughout the year. Areas are subdivided into the regions OS1 (inner part of Oosterschelde sea arm), OS2 (seaside "mouth" of the Oosterschelde sea arm), WS2 (seaside "mouth" of the Westerschelde estuary) and SNS (Dutch coastal zone in the Southern North Sea; Figure 1, small inset panels). All tagging activities were under licence of the Dutch Animal Welfare Act, project reference 2013170.a.

Between 2011 and 2019, the total number of reported recaptures was 220 (4.9\%; Table 1): 114 females (50-124 cm $L_{T}$ ), 102 males $\left(47-105 \mathrm{~cm} L_{T}\right)$ and four nonsexed $\left(56-100 \mathrm{~cm} L_{T}\right)$. For the statistical analysis, nonsexed fish were excluded, and juveniles and adolescents were pooled as immature fish. Time at liberty and minimum distance travelled (i.e., the distance between their places of tagging and recapture, measured in a straight line) between release and recapture ranged between 1-2476 days and $1-1541 \mathrm{~km}$ in females, and 1-1795 days and 1-999 in males, respectively.

At a smaller spatial scale, patterns in the distribution of female and male $M$. asterias in the capture data during summer (JuneSeptember) show that in the more sheltered areas adult females dominated the catches (82.4\% in OS1 and $43.8 \%$ in WS2), with fewer adult males $(6.9 \%$ and $24.3 \%)$ and immature fish present $(10.7 \%$ and $32.0 \%$ ). In contrast, relatively more adult males and immature fish were caught in more exposed sea areas, including SNS (27.2\% males and $71.1 \%$ immatures) and OS2 (21.5\% and 66.2\%) (Figure 1c,d; Chisquared test: $\left.\chi^{2}(6)=1106, P<0.001\right)$. This small-scale spatial sex differentiation in distribution in summer is most likely related to the use of OS1 and WS2 as pupping areas. Of all 66 pups ( $\left.<33 \mathrm{~cm} L_{T}\right), 65$ were caught during the warmest summer months (July and August) and one in September in these areas. This pattern is similar to that in many coastal sharks that use warm, sheltered, shallow waters to avoid predation of their pups (Speed et al., 2010).

At a larger spatial scale, seasonal patterns in recaptures of female and male M. asterias were visualized in maps using $\operatorname{ArcGIS}^{\circledR}$ software. Seasons were defined as spring (April and May), summer (JuneSeptember), autumn (October-November) and winter (DecemberMarch), with areas Northern North Sea, Central North Sea, Southern North Sea, English Channel, Bay of Biscay, Irish and Celtic Seas and North-east Atlantic. There are also apparent differences in large-scale spatial migration patterns between males and females across seasons (Figure 1). The distributions of female and male M. asterias differed significantly between areas in spring (Chi-squared test: $\chi^{2}(3)=12.4$, $P=0.006)$ and winter $\left(\chi^{2}(3)=9.22, P=0.027\right)$, with relatively more males in the Northern North Sea and more females in the Bay of Biscay. This sex differentiation was not apparent in summer $\left(\chi^{2}(2)=1.32\right.$, $P=0.516)$, or autumn $\left(\chi^{2}(2)=1.75, P=0.418\right)$. Sexual differentiation in the circannual migration pattern was also apparent from the minimum distance travelled of individual sharks. An ANOVA was performed on Box-Cox transformed minimum distances travelled to ensure normal and homoscedastic distribution of residuals. Minimum distance travelled was significantly affected by season $\left(F_{(3,177)}=48.7\right.$, $P<0.001, \omega=0.66$ ), with greater distances travelled in winter and spring, and by sex $\left(F_{(1,177)}=8.60, P=0.009, \omega=0.14\right)$, with females generally migrating farther (Table 1 ).

The analysis of captures and recaptures clearly shows sexdifferentiated migration patterns for $M$. asterias at several spatial scales. During summer, small-scale spatial sex differentiation was observed, where sheltered sea arms were almost exclusively used by adult females. During winter and spring, large-scale spatial sex differentiation was observed. Adult females migrated almost exclusively south to the English Channel and into the Bay of Biscay, while adult males partially migrated south to the English Channel and to the Northern North Sea, but rarely into the Bay of Biscay. Equal ratios of male and female M. asterias were observed in the English Channel. The short distances between the tagging locations and recaptures during subsequent summer months after tagging suggests a degree of philopatry. No recaptures occurred in the Irish and Celtic Seas, which implies the presence of separate subpopulations which use the Irish and Celtic Seas and the Southern North Sea for feeding and pupping.

Before the present mark-recapture study, sex-differentiated migration was unknown for M. asterias. It has, however, been described in a few other coastal shark species in the North-east Atlantic. For example, the cosmopolitan and highly mobile tope shark (Galeorhinus galeus) occurs in shallow coastal areas in the North-east Atlantic during the summer months (Compagno, 1984) and moves out

FIGURE 1 Seasonal distribution of (a) male and (b) female M. asterias, and distribution of immature life stages (juveniles, adolescents) and adults for (c) males and (d) females. Fish were captured and tagged in the Netherlands between April and October in 2011-2019 (small inset panels). Total length data in centimetres was obtained from McCully Phillips and Ellis (2015) to identify life stages, with $L^{50}$ for a division between pups $(<33 \mathrm{~cm})$, males: juveniles $(33-65 \mathrm{~cm})$, adolsecents $(65 \leq 70.4 \mathrm{~cm})$, adults $(>70.4 \mathrm{~cm})$, and females: juveniles $(33-69 \mathrm{~cm})$, adolescents $(69 \leq 81.9 \mathrm{~cm})$ and adults $>81.9 \mathrm{~cm})$ 


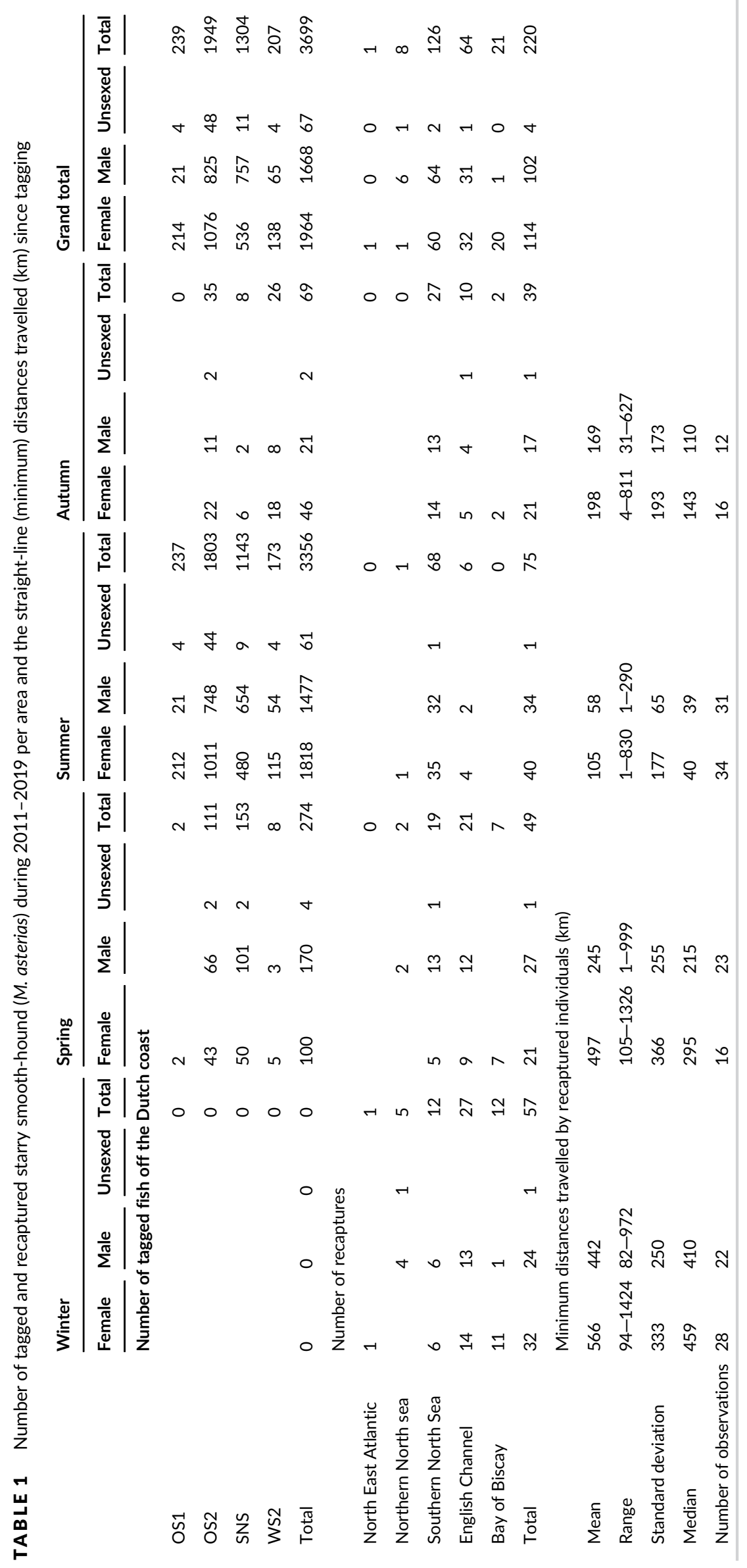


to deeper offshore waters during winter, with some mature females ranging further south to the Mediterranean (Colloca et al., 2019; Thorburn et al., 2019). The underlying causes of sex-specific migration in shark species are still largely unknown but Wearmouth et al. (2009) and Speed et al. (2010) suggested several potential causes for spatial separation of the sexes in sharks, including females avoiding mating, resource competition, diet, reduction in pup mortality, sex-specific habitat requirements and the thermal niche hypothesis. This hypothesis predicts the migration of females to warmer southern waters where metabolic rate is increased, consequently increasing the growth and development of embryos (Hurst et al., 1999). The temporal separation of certain adult female $M$. asterias that migrate to the Bay of Biscay during winter may be explained by their capacity to store sperm (Farrell et al., 2010a) and may enable them to conserve energy by limiting multiple matings during a time when embryonic development requires more energy: a principle that is also suggested in the dogfish, Scyliorhinus canicula (Sims et al., 2001). Another possibility is that in a cold-blooded viviparous species like $M$. asterias, pregnant females use wintering habitat with higher temperatures to increase embryonic development. In contrast, the occurrence of larger M. asterias males in the Northern North Sea may be related to the presence of important prey (McCully Phillips \& Ellis, 2015). Remarkably, none of the 3699 tagged M. asterias individuals in this present study were recaptured in the Central North Sea (ICES area 4.b.), nor in the Irish and Celtic Seas, despite intensive demersal fisheries in both areas, which is in line with philopatry to summer feeding and pupping grounds in M. asterias.

The results indicate that management of $M$. asterias should integrate both large (from the Northern North Sea to the Bay of Biscay) and smaller spatial and temporal scales, taking into account yearround movement patterns as well as specific feeding and pupping habitats. Moreover, management should also consider the existence of several subpopulations potentially coexisting in the coastal waters of western Europe. To further investigate this, a combination of tracking individual movements with telemetry and using different genetic techniques is advised.

\section{ACKNOWLEDGEMENTS}

This study was supported by the World Wide Fund for Nature (WWF) as part of the project "Sharks and rays back to the North Sea!" The authors express their sincere thanks to Monique van de Water, Georgina Wiersma and Peter Verhoog for their commitment to aid this study, with a priority focus to restore elasmobranchs in the North Sea. A great thank you goes out to all fishers that tagged the starry smooth-hounds and reported their recaptures.

\section{ETHICAL STATEMENT}

The care and use of experimental animals complied with the Dutch Animal Welfare Act, guidelines and policies as approved by the Centrale Commissie Dierproeven (Dutch Central Committee Animal Experiments), project reference 2013170.a.

\section{ORCID}

Niels W. P. Brevé (D) https://orcid.org/0000-0002-2152-3690

Hendrik V. Winter (D) https://orcid.org/0000-0003-1358-5899

Eleanor S. I. Greenway (D) https://orcid.org/0000-0001-7715-7987

Leopold A. J. Nagelkerke (D) https://orcid.org/0000-0003-1130-749X

\section{REFERENCES}

Brevé, N. W., Winter, H. V., Van Overzee, H. M., Farrell, E. D., \& Walker, P. A. (2016). Seasonal migration of the starry smooth-hound shark Mustelus asterias as revealed from tag-recapture data of an angler-led tagging programme. Journal of Fish Biology, 89, 1158-1177.

Burt, G. J., Silva, J. F., McCully, S. R., Bendall, V.A. and Ellis, J. R. (2013). Summary results from opportunistic tagging programmes for smoothhound Mustelus spp., greater-spotted dog-fish Scyliorhinus stellaris and tope Galeorhinus galeus around the British Isles. Working Document to the Working Group on Elasmobranch Fishes, Lisbon, Portugal, 17-21 June 2013, p. 12.

Colloca, F., Carrozzi, V., Simonetti, A., \& Di Lorenzo, M. (2020). Using local ecological knowledge of fishers to reconstruct abundance trends of elasmobranch populations in the strait of Sicily. Frontiers in Marine Science, 7, 508.

Colloca, F., Enea, M., Ragonese, S., \& Di Lorenzo, M. (2017). A century of fishery data documenting the collapse of smooth-hounds (Mustelus spp.) in the Mediterranean Sea. Aquatic Conservation: Marine and Freshwater Ecosystems, 27, 1145-1155.

Colloca, F., Scannella, D., Geraci, M. L., Falsone, F., Batista, G., Vitale, S., \& Di Lorenzo, M. (2019). British sharks in Sicily: records of long distance migration of tope shark (Galeorhinus galeus) from North-Eastern Atlantic to Mediterranean Sea. Mediterranean Marine Science, 20, 309-313.

Compagno, L. J. (1984). FAO species catalogue. Vol. 4. Sharks of the world. An annotated and illustrated catalogue of shark species known to date. Part 2. Carcharhiniformes. FAO fisheries synopsis, 125(4), 251655. http://www.fao.org/3/ad123e/ad123e00.htm.

Dulvy, N. K., Fowler, S. L., Musick, J. A., Cavanagh, R. D., Kyne, P. M., Harrison, L. R., ... Francis, M. P. (2014). Extinction risk and conservation of the world's sharks and rays. eLife, 3, e00590.

Farrell, E., Mariani, S., \& Clarke, M. (2010a). Reproductive biology of the starry smooth-hound shark Mustelus asterias: geographic variation and implications for sustainable exploitation. Journal of Fish Biology, 77, 1505-1525.

Farrell, E. D., Mariani, S., \& Clarke, M. W. (2010b). Age and growth estimates for the starry smoothhound (Mustelus asterias) in the Northeast Atlantic Ocean. ICES Journal of Marine Science, 67, 931-939.

Farrell, E. D., O'Sullivan, N., Sacchi, C., \& Mariani, S. (2014). Multiple paternity in the starry smooth-hound shark Mustelus asterias (Carcharhiniformes: Triakidae). Biological Journal of the Linnean Society, 111, 119-125.

Hurst, R. J., Baglet, N. W., McGregor, G. A., \& Francis, M. P. (1999). Movements of the New Zealand school shark, Galeorhinus galeus, from tag returns. New Zealand Journal of Marine and Freshwater Research, 33, 29-48.

ICES (2019). Working Group on Elasmobranch Fishes (WGEF). ICES Scientific Reports. 1:25. p. 964. http://doi.org/10.17895/ices.pub.5594.

McCully Phillips, S. R., \& Ellis, J. R. (2015). Reproductive characteristics and life-history relationships of starry smooth-hound Mustelus asterias in British waters. Journal of Fish Biology, 87, 1411-1433.

Musick, J. A., Burgess, G., Cailliet, G., Camhi, M., \& Fordham, S. (2000). Management of sharks and their relatives (Elasmobranchii). Fisheries, 25(3), 9-13.

Myers, R. A., Baum, J. K., Shepherd, T. D., Powers, S. P., \& Peterson, C. H. (2007). Cascading effects of the loss of apex predatory sharks from a coastal ocean. Science, 315, 1846-1850. 
Nieto, A., Ralph, G. M., Comeros-Raynal, M. T., Heessen, H. J. L., \& Rijnsdorp, A. D. (2015). European red list of marine fishes, Luxembourg: Publications Office of the European Union.

Silva, J. F., \& Ellis, J. R. (2019). Bycatch and discarding patterns of dogfish and sharks taken in English and Welsh commercial fisheries. Journal of Fish Biology, 94, 966-980.

Sims, D., Nash, J., \& Morritt, D. (2001). Movements and activity of male and female dogfish in a tidal sea lough: alternative behavioural strategies and apparent sexual segregation. Marine Biology, 139, 1165-1175.

Speed, C. W., Field, I. C., Meekan, M. G., \& Bradshaw, C. J. (2010). Complexities of coastal shark movements and their implications for management. Marine Ecology Progress Series, 408, 275-293.

Stevens, J., Bonfil, R., Dulvy, N., \& Walker, P. (2000). The effects of fishing on sharks, rays, and chimaeras (chondrichthyans), and the implications for marine ecosystems. ICES Journal of Marine Science, 57, 476-494.

Thorburn, J., Neat, F., Burrett, I., Henry, L.-A., Bailey, D., Jones, C., \& Noble, L. (2019). Ontogenetic and seasonal variation in movements and depth use, and evidence of partial migration in a benthopelagic elasmobranch. Frontiers in Ecology and Evolution, 7, 353.
Wearmouth, V. J., Southall, E. J., Morritt, D., Thompson, R. C., Budd, G. C., Partridge, J., \& Sims, D. (2009). Sexual segregation as a behavioural mediator of elasmobranch population dynamics. In Comparative biochemistry and physiology A-molecular \& integrative physiology (vol. 153, p. S67). Elsevier: Amsterdam, Netherlands. https://doi.org/10.1016/j. cbpa.2009.04.014.

Williamson, M. J., Tebbs, E. J., Dawson, T. P., \& Jacoby, D. M. (2019). Satellite remote sensing in shark and ray ecology, conservation and management. Frontiers in Marine Science, 6, 135.

How to cite this article: Brevé NWP, Winter HV Wijmans PADM, Greenway ESI, Nagelkerke LAJ. Sex differentiation in seasonal distribution of the starry smoothhound Mustelus asterias. J Fish Biol. 2020;1-6. https://doi.org/ 10.1111/jfb.14548 